Received: Sep 25, 2018; Accepted: Oct 16, 2018; Published: Oct 31, 2018; Paper Id.: IJASRDEC20186

\title{
INTRODUCTION
}

Chemical pesticides have contributed greatly to the increase of yields in agriculture by controlling pests and diseases and also towards checking the insect-borne diseases in the human health sector. The need to increase world food production for the rapidly growing population is well recognized. One of the strategies to increase crop productivity is an effective pest management because more than 45 percent of annual food production is lost to pest infestation. Through overuse and misuse there is considerable waste, adding to the cost and contributing to the adverse environmental and health consequences. The consumption level of pesticides in India is the lowest in the world. It uses a low amount of $0.5 \mathrm{~kg} /$ hectare pesticides compared to $12.0 \mathrm{~kg} /$ hectare by Japan, $7.0 \mathrm{~kg} /$ hectare by USA, $6.6 \mathrm{~kg}$ / hectare by Korea and $2.5 \mathrm{~kg}$ / hectare by Europe (Suresh and Varshney, 2008). Modern, intensive agriculture produces significant negative externalities of pesticide applications.

The Indian pesticide production industry started with the setting up of a BHC technical plant at Rishra near Kolkata in 1952 (Abhilash and Singh, 2009). The optimizing chemical dose is an essential component of integrating pesticide use with other non- chemical strategies. In this regard, most European fruit growers are found to be aware of community and government concerns with the indiscriminate and inefficient use of agricultural chemicals (Furness, et al., 1998). 
Hydraulic nozzles were traditionally made in brass (or sometimes stainless steel), but hardwearing engineering plastics are now most commonly used. If nozzle wear from abrasive particles is a special problem, some manufacturers supply ceramic tips inserted into a plastic mounting. If an unsuitable plastic is used in nozzle manufacture, water can be absorbed initially by the plastic affecting the flow rate by changes in the size of the orifice (Anon, 2004).

Jose (1987) compared three different nozzles (namely $5025030 \mathrm{~N}, 6045030 \mathrm{~N}$ and 80450 NMD/S, ASPEE XLC SPJ) for their performance. The parameters like discharge, cone angle, droplet size and spray distribution were measured for each type of nozzle at a spray pressure of $3 \mathrm{~kg} / \mathrm{cm} 2$. It was observed from droplet spectrum analysis that the ratio of VMD to NMD (2.83) was maximum for the nozzle 80450 and minimum for the nozzle 60450 and 2.64 for the 50250. It was observed that the spray nozzle (60450) gave better performance. Discharge rates of $425 \mathrm{cc} / \mathrm{min}$ were obtained with 60450 nozzles at a cone angle of 70o compared to $235 \mathrm{cc} / \mathrm{min}$ were obtained with 50250 nozzle and $450 \mathrm{cc} / \mathrm{min}$ with 80450 nozzle for cone angle of 50o and 940 respectively.

\section{THEORETICAL CONSIDERATIONS}

\section{The Required Discharge Rate of the Power Operated Hydraulic Spray System}

Pesticide application is an important agricultural operation to increase the crop yield by control the pests and diseases. The quantity of pesticide application rate varies from crop to crop. Now a day's different types of liquid spray equipment are available in the market. The discharge rate and spray angle are mainly depends upon the type of spray nozzle and operating pressure. The discharge rate of different types of spray nozzles vary from minimum as $172 \mathrm{ml} / \mathrm{min}$ to maximum as $1350 \mathrm{ml} / \mathrm{min}$ per one spray nozzle (varshney, 1997). The availability of this data and the designed spray Patternator (it is having the two spray nozzles), the power operated hydraulic spray system was designed to meet the desired discharge of $2.01 \mathrm{t} / \mathrm{min}$ with the pressure ranges from $1 \mathrm{~kg} / \mathrm{cm}^{2}$

\section{Estimation of Power Requirement of Electrical Motor}

$$
\begin{aligned}
& \text { Maximum system pressure }=10.0 \mathrm{~kg} / \mathrm{cm}^{2} \\
& =100.43 \text { meters } \\
& \text { Maximum flow-rate } \quad=2.0 \mathrm{lit} / \mathrm{min} \\
& \text { Theoretical power requirement }=\text { discharge rate } \times \text { pressure, }((\mathrm{L} / \mathrm{S}) \times(\mathrm{m} / 75) \\
& =0.045 \mathrm{hp}
\end{aligned}
$$

\section{Power Losses}

$$
\begin{aligned}
& \text { Pump mechanical efficiency }=85 \% \\
& \text { Pump volumetric efficiency }=85 \% \\
& \text { Power transmission efficiency }=90 \% \\
& \text { Motor efficiency }=85 \% \\
& \text { Overall efficiency }=55.2 \%
\end{aligned}
$$

Actual power requirements $=(0.045) / 0.552$ 
Actual power requirements $=0.081 \mathrm{hp}$

\section{Estimation of Discharge-Rate of the Pump}

The measured outside diameter of the cylinder $=5.25 \mathrm{~cm}$

Assumed thickness of the cylinder $=3 \mathrm{~mm}$

The inside diameter of the cylinder $=5.25-(2 \times 0.3)$

The measured stroke- length of the pump $=6.3 \mathrm{~cm}$

The discharge rate of the pump per stroke $=(\pi \div 4)(4.65 \times 4.65) \times 6.3$

The discharge rate of the pump per stroke $=0.102$ liters

\section{Determination of Intermediate Circular Shaft Diameter}

A shaft is rotating machine element which is used to transmit power from one place to another. The power is delivered to the shaft by some tangential force and the resultant torque set up within the shaft permits the power to be transferred to various machines linked up to the shaft.

Shaft speed $(\mathrm{N})=320 \mathrm{rpm}$

Power of electrical motor $(\mathrm{p})=1 \mathrm{hp}(745 \mathrm{~W})$

Diameter of circular shaft $(\mathrm{d})=1.5 \mathrm{~cm}$

\section{Design of Pump and its Drive}

Speed of an electrical motor $=1460$ RPM

The discharge rate of the pump per stroke $=0.102$ liters (from article 3.3)

The required speed of the pump to deliver $2.0 \mathrm{lit} / \mathrm{min}=2 / 0.102$

Required pump speed to deliver 2 liters of water per minute $=20$ strokes $/ \mathrm{min}$

Number of teeth on small (pinion) spur gear $\left(\mathrm{T}_{3}=\mathrm{T}_{5}\right)=21$

Number of teeth on large spur gear $\left(\mathrm{T}_{6=} \mathrm{T}_{4}\right)=84$

The required speed of the shaft- $4\left(\mathrm{~N}_{4}\right)=20 \mathrm{rpm}$

The theoretical speed of the shaft- $3\left(\mathrm{~N}_{3}\right)=80 \mathrm{rpm}$

The theoretical speed of the shaft- $2\left(\mathrm{~N}_{2}\right)=(80 \times 84) / 21 \mathrm{rpm}$

The theoretical speed of the shaft- $2\left(\mathrm{~N}_{2}\right)=320 \mathrm{rpm}$

The speed of an electrical motor $\left(\mathrm{N}_{1}\right)=1460 \mathrm{rpm}$

The minimum diameter of the small pulley $=5 \mathrm{~cm}$

The required diameter of the large pulley $\left(D_{2}\right)=(1460 \times 5) / 320$

The required diameter of the large pulley $\left(D_{2}\right)=22.81 \mathrm{~cm}$ 


\section{Assume Slip as 2 Percent}

The required diameter of the large pulley $\left(\mathrm{D}_{2}\right)=23.27 \mathrm{~cm}$

\section{Piston or Plunger Pump}

The heart of the pumping unit is the hydraulic pump. Therefore a pump of 2 lit/min capacity and rated speed of 20 strokes/ min was selected on the basis of flow requirement, operating pressure and availability.
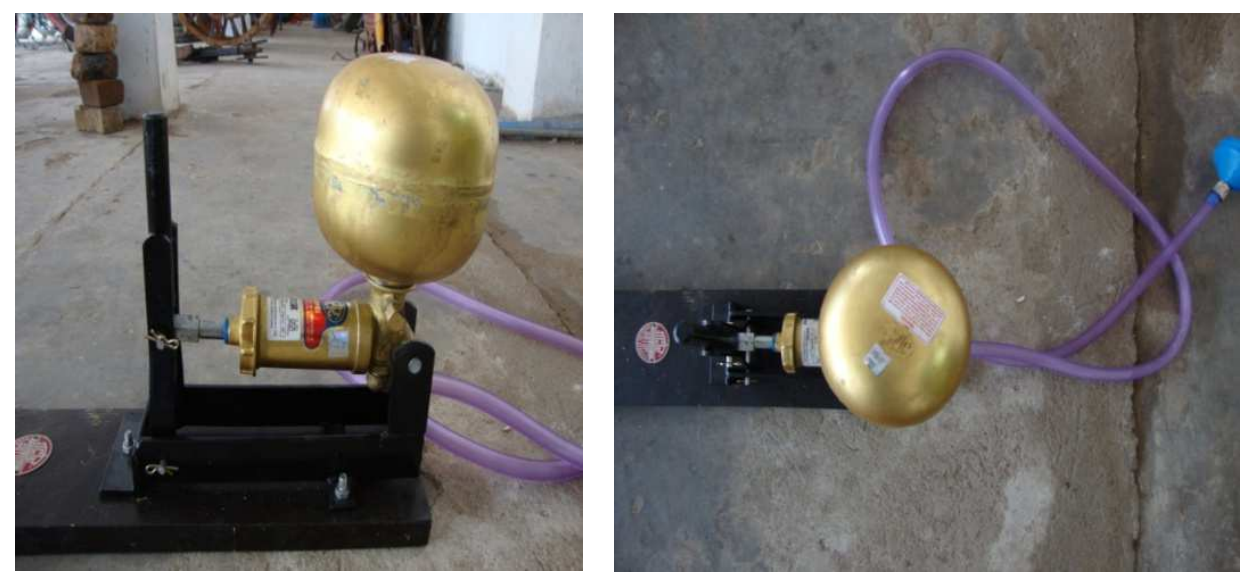

Figure 1: Piston Pump

The volumetric efficiency of plunger pump is generally high ( 90 percent or more), and a discharge rate is essentially a direct function of crank speed and volumetric displacement. Mechanical efficiencies may range from 50 to 90 percent, depending on the size and condition of the pump.

\section{Technical Specifications}

Pressure vessel $=$ Brass sheet 18 swg

Pump barrel $=$ Brass

Pressure Chamber capacity $=2200 \mathrm{cc}$

Pressure $=5.62-6.32 \mathrm{~kg} / \mathrm{cm}^{2}(80-90 \mathrm{psi})$

Piston stroke length $=6.3 \mathrm{~cm}$

Outside diameter of the cylinder $=5.25 \mathrm{~cm}$

\section{Electrical Motor}

An electrical motor is the power source in the power operated hydraulic pumping system. The piston pump gets the power from an electrical motor. According to the power requirements, availability and convinces, motor have been selected. The following are the technical specifications:

\section{Technical Specifications of Electrical Motor}

Electrical motor power $=1 \mathrm{HP}(0.75 \mathrm{~kW})$

Motor pulley shaft speed $=1440 \mathrm{rpm}$

Voltage $=440 \mathrm{~V}$ 
Current $=1.9$ amps

The spur gears, V- belt, pulleys and intermediate shafts are selected based on the speed reduction and power requirements.

\section{Hydraulic Pump and its Drive}

The heart of the pumping unit is the hydraulic pump. Therefore, a pump of 2 lit/min capacity and rated speed of $24 \mathrm{rpm}$ was selected on the basis of flow requirement, operating pressure and availability. To drive the pump, V- belt, spur gears, pulleys and intermediate circular shafts were selected according to the requirement. All the technical specifications of an electric motor and hydraulic pump are given in 1 .

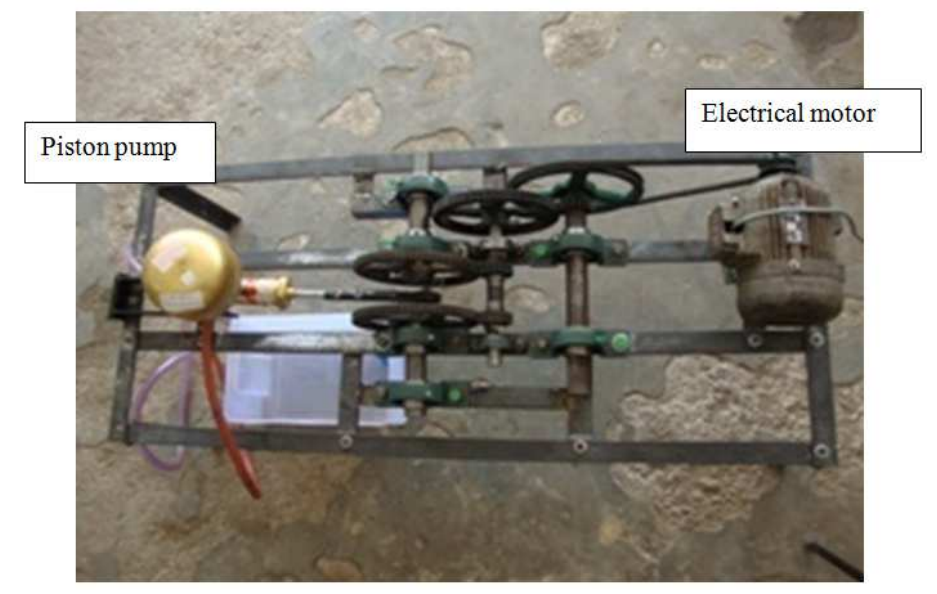

Figure 2: Assembly Layout of Hydraulic Pump and its Drive

\section{Determination of Stroke - Length of the Pump}

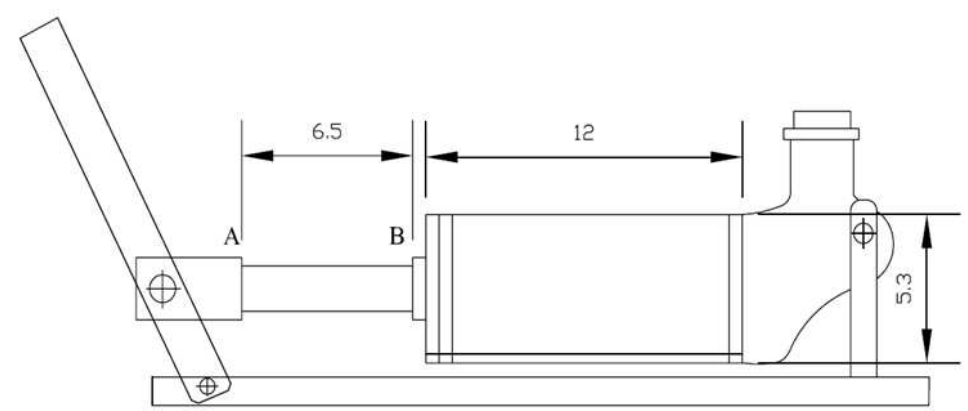

All dimensions are in $\mathrm{cm}$.

Figure 3: Determination of Stroke - Length of the Pump

The pump consists of piston, connecting rod, cylinder and handle mounted on the frame. The connecting rod is attached to the piston at one end and the handle on the other end. The lower end of the handle is bolted to the frame at hand lever pivot point and upper end for holding the handle with hand. The piston makes compression and tension strokes by moving the handle forward and backward directions.

The handle pushed forward still piston reach the cylinder right end and put a mark on the piston connecting rod as point ' $\mathrm{A}$ ' then again handle pulled backward till the piston reach the cylinder left end and put a mark at point 'B' on the connecting rod (as shown in figure 4). The distance between the two points A and B (from A to B) as shown in the figure 
3. give the stroke- length of the pump. The measured stroke- length of the pump between two points A and B was 63 mm.

\section{Determination of Diameter of the Pump Cylinder}

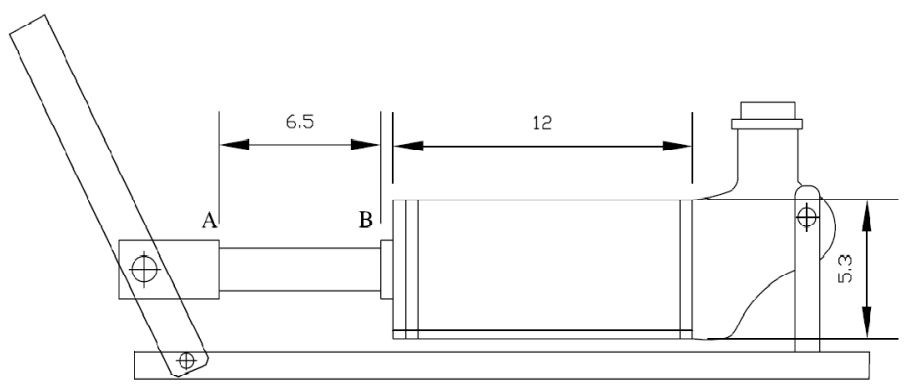

Figure 4: Determination of the Diameter of the Pump Cylinder

The circumference of the hydraulic pump cylinder (Figure 2) was measured by using the thread and scale. The thread wounded one full circle on the pump cylinder, that wounded thread length measured with the help of a scale as $16.5 \mathrm{~cm}$. The outer diameter of the hydraulic pump cylinder can get by using below mathematical relation:

Circumference of the hydraulic pump cylinder $=\pi \times \mathrm{D}$

$=16.5 / \pi$

Outer diameter of the hydraulic pump cylinder $(\mathrm{D})=5.25 \mathrm{~cm}$

\section{Measurement of Discharge- Rate of the Pump}

The experiment of discharge rate of the pump was conducted in the Farm Machinery Laboratory of the Agricultural and Food Engineering Department. The pump, bucket with full of water, graduated cylinder and two persons required for conducting the experiment. The suction pipe of the pump with strainer kept in the bucket filled with water. Before starting the experiment, one person operated hand operate hydraulic pump with uniform speed and other person collected the spray liquid at the end of the spray nozzle into another bucket for 5 strokes. The collected liquid was measured with the help of the graduated cylinder. The experiment was repeated for four times. The average discharge-rate (52.5 $\mathrm{ml}$ per stroke) taken as the measured discharge rate of the pump. The measured discharge rate divides with the number of strokes will give the discharge rate per stroke.

\section{Material Requirement}

The following materials are mainly required for the design of power operated hydraulic spray system, they are;

- $\quad$ Piston ump and Electrical motor (0.081hp) assembly base

- $\quad$ Mild steel pulley-1diameter $23 \mathrm{~cm}$ (one piece)

- $\quad$ Mild steel pulley-2 diameter $5 \mathrm{~cm}$ (one piece)

- $\quad$ Mild steel spur gears diameter $6 \mathrm{~cm}$ (3 pieces)

- $\quad$ Mild steel spur gears diameter $23 \mathrm{~cm}$ (3 pieces)

- Mild steel circular shaft-1 diameter $2.8 \mathrm{~cm}$ of length $32 \mathrm{~cm}$ 
- Mild steel circular shaft-2 diameter $3 \mathrm{~cm}$ of length $29 \mathrm{~cm}$

- Mild steel circular shaft-3 diameter $4 \mathrm{~cm}$ of length $26 \mathrm{~cm}$

- Mild steel circular shaft-4 diameter $4 \mathrm{~cm}$ of length $20 \mathrm{~cm}$

- V- belt

\section{Piston Pump and Electrical Motor (0.081hp) Assembly Base}

Pump and its driving mechanism will be mounted on a metal frame having $130 \mathrm{~cm}$ length and $60 \mathrm{~cm}$ width, and made of mild steel angle section $(37.5 \times 37.5 \mathrm{~mm})$. The overall height of the base will be $350 \mathrm{~mm}$ from the ground.

For considerable reduction in electrical motor speed an intermediate shafts, pulleys and gear mechanism will be fabricated for which a pulley and gear driving shafts will be required.

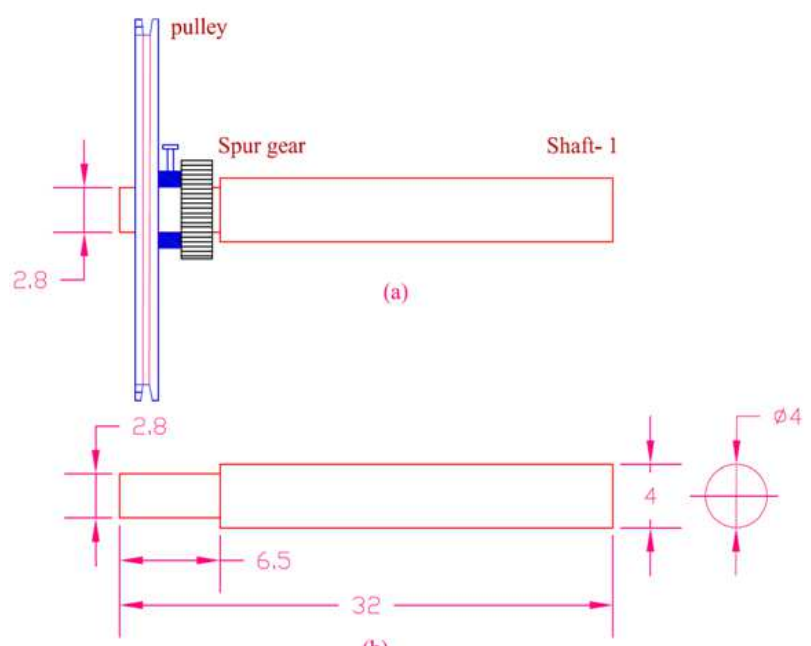

(b)

All dimensions are in $\mathrm{cm}$

Figure 5: Drawing of Pulley, Spur Gear and Shaft-1
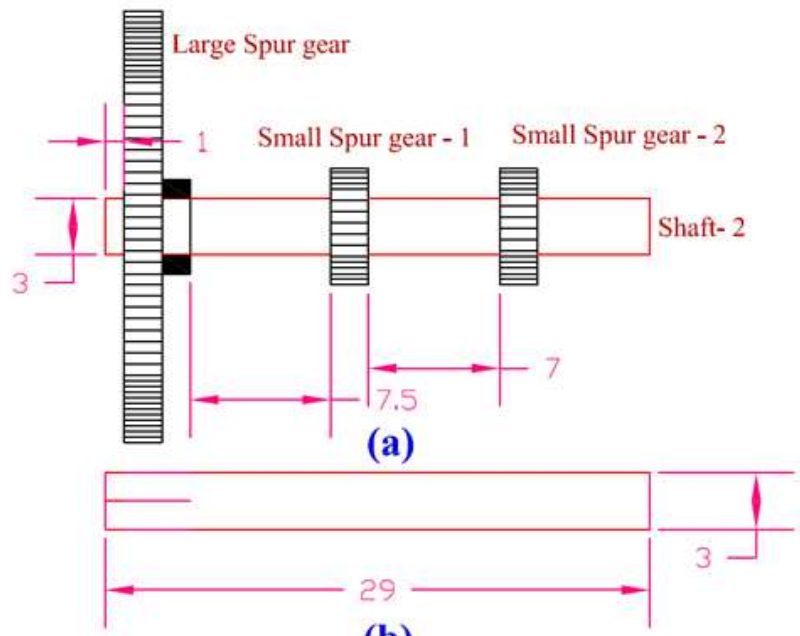

(b)

All dimensions are in $\mathrm{cm}$

Figure 6: Drawing of Spur Gears and Shaft-2 

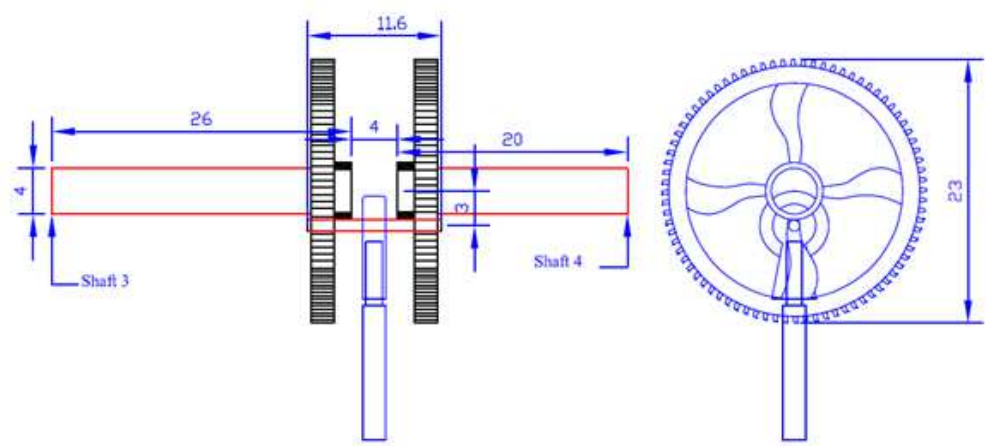

All dimensions are in $\mathrm{cm}$

Figure 7: Drawing of Shaft 3 \& 4, spur Gears with Fulcrum Mechanism

\section{RESULTS AND DISCUSSIONS}

\section{Pump Efficiency}

The sprayer wad operated at a specified speed and at four pressure stages covering maximum pressure $5 \mathrm{~kg} / \mathrm{sq} . \mathrm{cm}$ and minimum $3 \mathrm{~kg} / \mathrm{sq}$. cm. The spray was collected in receiving vessel for a period of $60 \pm 1$ second. The amount of liquid collected shall be measured with an accuracy of \pm 2.5 percent. The collected volume of liquid in 2 min was $350 \mathrm{ml}$.

Calculated discharge rate of the pump per stroke $=102 \mathrm{ml}$ (from article 3.2)

Actual measured discharge rate of the pump $=88.0 \mathrm{ml}($ from table 1)

Pump efficiency $=($ actual discharge $/$ calculated discharge $) \times 100$

Pump efficiency $=(88 \div 102) \times 100$

Pump efficiency $=86$ percent

\section{Measured Discharge Rate of the Pump}

The hydraulic pump delivery pipe connected to the patternator inlet. The patternator has the two spray nozzles and two pressure gauges over the two spray nozzles. The hydraulic pump was operated at four stages of pressure covering the minimum $(3 \mathrm{~kg} / \mathrm{sq} . \mathrm{cm})$ and maximum $(7 \mathrm{~kg} / \mathrm{sq} . \mathrm{cm})$ and at 21 strokes per minute for 30 minutes. The sprayed liquid (clean water) was collected in the test tubes at the bottom side of the spray patternator and the observations were tabulated as follows.

Table 1: Discharge Rate of Spray Nozzle with Orifice Diameter of $0.70 \mathrm{~mm}$ at $6 \mathrm{~kg} / \mathrm{cm}^{2}$ Pressure

\begin{tabular}{|c|c|c|c|c|c|c|}
\hline $\begin{array}{c}\text { Specified } \begin{array}{c}\text { Speed } \\
\text { rev/min }\end{array} \\
\text { Wressure }\end{array}$ & $\begin{array}{c}\text { Working } \\
\text { [g/cm }\end{array}$ & Test no & \multicolumn{2}{|c|}{$\begin{array}{c}\text { Discharge from each } \\
\text { Nozzle ml/min }\end{array}$} & $\begin{array}{c}\text { Average } \\
\text { Discharge } \\
(\mathbf{m l})\end{array}$ & $\begin{array}{c}\text { Total } \\
\text { Discharge } \\
(\mathbf{m l})\end{array}$ \\
\cline { 4 - 5 } & & 1 & 920 & 910 & 915 & 1830 \\
\hline 21 & 6 & 1 & 930 & 915 & 922.5 & 1845 \\
\hline 21 & 6 & 2 & 925 & 910 & 917.5 & 1835 \\
\hline 21 & 6 & 3 & 925 & Nozzle(2) & \\
\hline & 6 & 4 & 930 & 920 & 925 & 1850 \\
\hline & & Average & $\mathbf{9 2 6 . 2 5}$ & $\mathbf{9 1 3 . 7 5}$ & $\mathbf{9 2 0}$ & $\mathbf{1 8 4 0}$ \\
\hline
\end{tabular}




\section{Spray Distribution}

The spray angle was measured with the help of two leg protector, the discharge rate of the pump was measured with a test tube and the measured values were tabulated below.

Table 2: Working Pressure and Spray Angle of Orifice Diameter of $0.70 \mathrm{~mm}$ at Various Pressures

\begin{tabular}{|c|c|c|c|c|}
\hline $\begin{array}{c}\text { Working Pressure, } \\
\mathbf{k g} / \mathbf{c m}^{\mathbf{2}}\end{array}$ & $\begin{array}{c}\text { Height of } \\
\text { Nozzle, } \mathbf{c m}\end{array}$ & $\begin{array}{c}\text { Quantity of Liquid } \\
\text { from 2 Nozzles ml/min }\end{array}$ & $\begin{array}{c}\text { Working } \\
\text { Width, cm }\end{array}$ & $\begin{array}{c}\text { Spray Angle in } \\
\text { Degrees }\end{array}$ \\
\hline 3 & 50 & 30.16 & 112.5 & 54 \\
\hline 4 & 50 & 30.33 & 115 & 60 \\
\hline 5 & 50 & 30.41 & 117.5 & 67 \\
\hline 6 & 50 & 30.58 & 120 & 75 \\
\hline 7 & 50 & 30.75 & 122.5 & 80 \\
\hline
\end{tabular}

Nozzle height $=50 \mathrm{~cm}$, Nozzle space $=50 \mathrm{~cm}$

The working width of the spray pattern increased along with pressure and the spray angle also increased with pressure, but the drift became a problem due to the size of the droplets slightly reduced.

Table 3: Working Pressures and Spray Angle of Orifice Diameter of $0.70 \mathrm{~mm}$ at Various Pressures

\begin{tabular}{|c|c|c|c|c|}
\hline $\begin{array}{c}\text { Working } \\
\text { Pressure, kg/cm }\end{array}$ & $\begin{array}{c}\text { Height of } \\
\text { Nozzle, cm }\end{array}$ & $\begin{array}{c}\text { Quantity of Liquid } \\
\text { from 2 Nozzles ml/min }\end{array}$ & $\begin{array}{c}\text { Working } \\
\text { Width, cm }\end{array}$ & $\begin{array}{c}\text { Spray Angle } \\
\text { in Degrees }\end{array}$ \\
\hline 3 & 55 & 30.16 & 115 & 54 \\
\hline 4 & 55 & 30.33 & 117.5 & 60 \\
\hline 5 & 55 & 30.41 & 120 & 67 \\
\hline 6 & 55 & 30.58 & 122.5 & 75 \\
\hline 7 & 555 & 30.75 & 125 & 80 \\
\hline
\end{tabular}

Nozzle height $=55 \mathrm{~cm}$, Nozzle spacing $=50 \mathrm{~cm}$

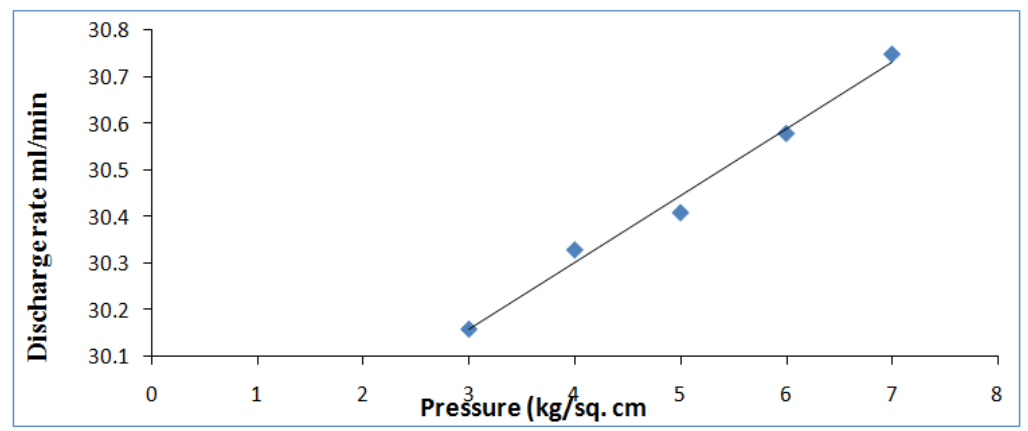

Figure 8: Pressure - Discharge Relation of Orifice Diameter $0.70 \mathrm{~mm}$

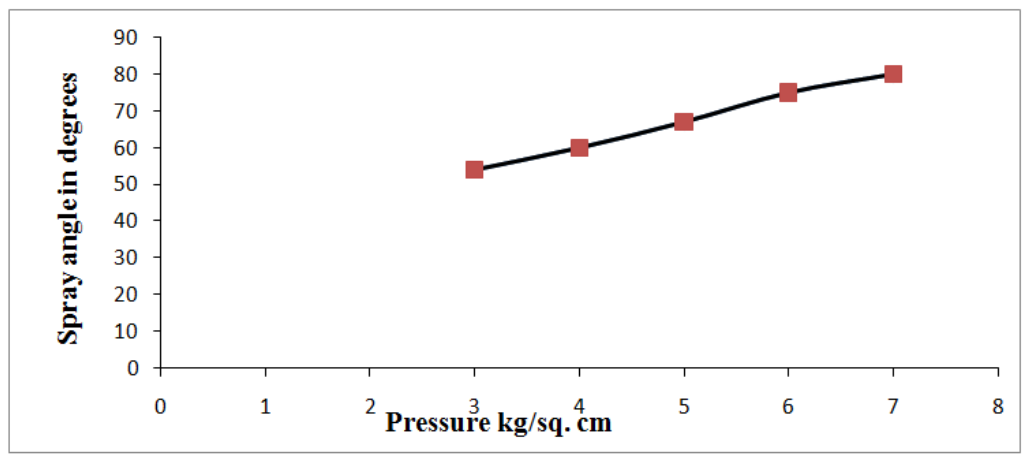

Figure 9: Pressure - Spray Angle Relation of Orifice Diameter 0.0.70 mm 


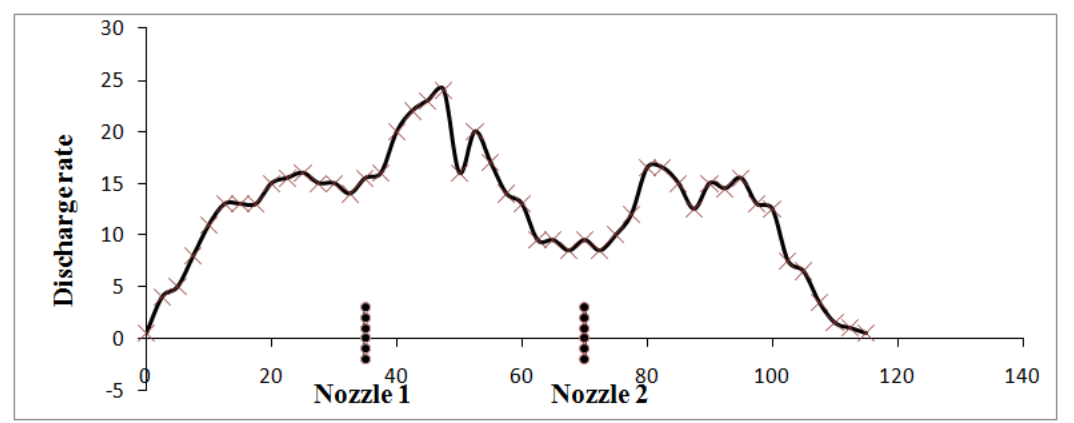

Figure 10: Lateral Distance- Discharge Rate Relation of Boom Height 48 cm

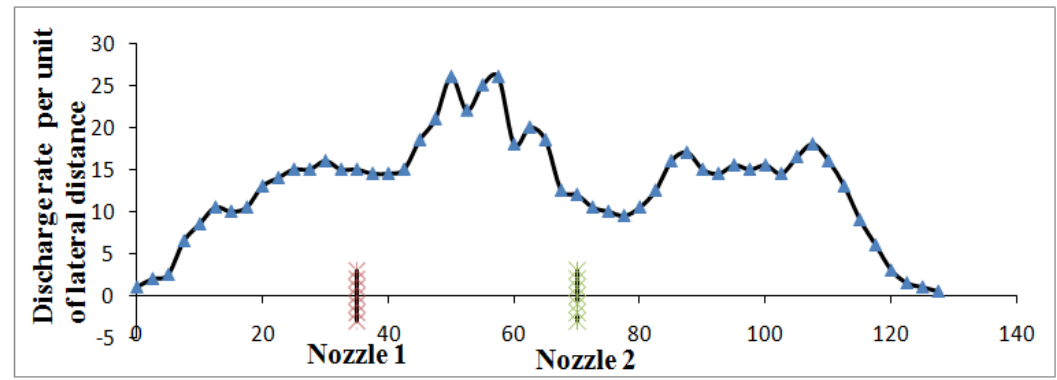

Figure 11: Lateral Distance - Discharge Rate of Boom Height $54 \mathrm{~cm}$

\section{CONCLUSIONS}

- In all cases as pressureincreases discharge also increases and spray angle also increase along with the pressure.

- The spray angle increased by the pressure after reaching to a maximum pressure, the spray angle slightly increased.

- As the operating pressure increases the droplet size decreases. It is, therefore, important to realize that while increasing the application rate by increasing pressure, the droplet size would decrease and may result in higher drift.

- The nozzle height also a one of the major components plays an important role in uniform coverage of the spray pattern.

\section{REFERENCES}

1. Anon. (2001). A Summary of Tank Mix and Nozzle Effects on Droplet Size. Spray Drift Task Force, Stewart Agricultural Research Services, Inc., Macon, Missouri, USA http://www.agdrift.com/PDF_FILES/Tankmix.pdf.

2. Anon, (2004). IPARC Guide No. 1 Hydraulic Spray Nozzles (Version 22/11/2004). The International Pesticide Application Research Center, Imperial College of Science, Technology and Medicine, Silwood Park, Scoot, Berkshire, UK, http:/ $/ w w w . d r o p d a t a . n e t / b c p c \_e w g / I P A R C \_s p r a y \_p r o t o c o l-h y d . p d f$.

3. Abhilash, P. C. and Singh, N. (2009). Pesticide use and Application: An India Scenario. Journal of Hazardous Materials 165 (2009) $1-12$.

4. Hagers, J. J. (1997). Basic Technical Considerations for Application of Spray Nozzles to Chemical Processing. Paper presented at Javits Convention Centre, New York, November18 - 20, 1997. 
5. Hewitt, A. J. (1998). The Importance of Nozzle Selection and Droplet Size Control in Spray Application. Paper Presented at North America Conference on Pesticide Spray Drift Management, March 29 - April 1, 1998, Portland, Maine.

6. Hewitt, A. J. (2005). International Standards for Drift Reduction Technology Studies. Paper Presented on OECD Workshop, 30 November 2005, http://www.oecd.org/dataoecd/48/44/37237952.pdf.

7. Kepner, R. A., Bainer, R. and Barger, E. L. (1978). Principle of Farm Machinery, Third Edition. CBS Publishers and Distributors, New Delhi, India, pp. 282- 310.

8. Mtthews, G. A. and Bateman, R. P. (2004). Classification of Criteria for Fog and Mist Application of pesticide. The International pesticide Application Research Center, Department of Biological science, Imperial College of Science, Technology And Medicine, Silwood park, Ascot, Bershire, U. K.

9. Monte, P. J., Entomology and Swetnam, L. D. (1996). Spray nozzle Selection and Calibration. Cooperative Extension Service, University of Kentucky, College of Agriculture, U. K.

10. Al-Shaheen, M. R., Soh, A. W. A. N. G., \& Al-Samarai, G. F. (2014). Growth responseof corn (Zea Maize L.) To proline and gibberellic acid spray under different irrigation levels. International Journal of Botany and Research (IJBR), 4(6), 7-16.

11. Poudel, R. (2009). Design and Development of Spray Patternaor, Unpublished, M. Tech. Thesis, Agricultural \& Food Engineering Department. Indian Institute of Technology, Kharagpur, India, pp. 5 - 38.

12. Richardson, R. G., Combellack, J. H. and Leah, A. (1986). Evaluation of a Spray Nozzle Patternator. Crop protection, 5(1): 8 -11 .

13. Schick, J. R. (2008). Spray Technology Reference Guide: Understanding Drop Size. Spray Analysis and Research Services, Bulletin No 459c. P. O. Box 7900, Wheaton, U. S. A.

14. Srivastava, A. J., Goering, E. C. and Rohrbach, P. R. (1993). Engineering Principles of Agricultural Machines. American Society of Agricultural Engineers Publishers. St. Joseph, Michigan 49085 - 9659, U. S. A. pp. 278 - 32. 
